lowered the stocking capacity that overstocking on established farms is now almost unavoidable. Rabbits have added to the evil, the vegetation cannot recover after grazing, and natural regeneration of both shrubs and grasses has virtually ceased. Large areas have become barren deserts, and no measures are available for their reclamation. The evil might be checked by adopting a lower stocking policy; but the only hope for the already denuded areas is to introduce perennial exotic plants capable of stabilizing the large sand drifts, and withstanding rabbits and a very low and uncertain rainfall. The chance of discovering such plants is remote, and even if discovered, "there would remain the problem of their dissemination through vast areas with no regular growing season and an unimproved capital value rarely exceeding 2s. per acre".

\section{Mining in Canada}

WE have received the Report of the Department of Mines of the Dominion of Canada for the fiscal year ended March 31, 1935, and taken as a whole it may be said to be thoroughly satisfactory. The Report shows that the rise in the price of gold has caused renewed activity in that industry and states that "Canada's gold industry is contributing to the prosperity, not only of the communities in which operations are centred, but to the industrial life of the nation as a whole". Canada apparently is also reopening some of the silver camps for which it was famous a few years ago, but the "Department's work in fuels and non-metallics is becoming of increasing economic importance", and there has been a relatively small number of ore treatment investigations in connexion with base metal ores. There are full reports of the various divisions of the Department of Mines, commencing with a Bureau of Economic Geology, the National Museum of Canada and Mines Branches proper, together with an Explosives Division, an Editorial Division and an Accounting Division, which latter shows that something like a million dollars was available for the expenditure of the Department of Mines, and that nearly all of it was utilized. It is interesting to note that the Fuels and Fuel Testing Division was busily engaged throughout the year in question.

\section{Cotton Research in India}

INDIA is the second largest cotton growing country in the world, and the importance of the industry led the Indian Cotton Committee to set up a Technological Laboratory at Matunga some ten years ago. Research work and tests of direct importance to the cotton breeder, merchant and mill owner have been carried out in collaboration with the provineial agricultural departments, and a brochure has just been published by the Committee giving a full account of the activities of the Laboratory since its inception (Bombay: Indian Central Cotton Committee. 2 rupees). The two main objects of the work are to undertake spinning tests on improved varieties of cotton, and to establish relationships between the measurable fibre characteristics and the spinning quality. This second object aims at dispensing with the necessity of making spinning tests on large numbers of new strains, as it is hoped to be able to assess the performance of the cotton from a knowledge of its fibre properties. The development of the work may be judged from the fact that during 1933-34, 166 samples were tested in connexion with trade and technological problems, compared with only 28 in 1924-25, while as regards agricultural samples, 366 were tested in 1933-34, compared with 46 in the 1924-25 season. The problem of averting the possible danger of the introduction of the cotton bollweevil through imported American bales has been successfully attacked. A satisfactory method of fumigation has been developed, and legislation enacted to ensure that all cottons imported from America are so treated. The brochure concludes with a complete list of publications issued from the Laboratory since 1925.

\section{The Science Museum Library}

ON entering a library for the purpose of obtaining information on a given subject, the first things the visitor wishes to know are what books or pamphlets the library possesses relating to the subject, and how is he to obtain them. There are usually card indexes available, but even with these at his disposal the reader may well be at sea unless he possesses a key to the system on which they are arranged. The publication of a new edition of the "Classification for Works on Pure and Applied Science in the Science Museum Library" (London : H.M. Stationery Office. 5s. net.) provides such a key to the finest science library in Great Britain. It should be studied by every one who uses the Library. It contains an explanation of the Universal Decimal Classification of the International Institute of Documentation in use at the Library, a list of about six thousand classes into which knowledge is divided for the purpose of indexing, and a copious alphabetical index comprising some five thousand entries. In the preface to the "Classification", Dr. S. C. Bradford says : "The titles on the cards in the Subject Catalogue are numbered and arranged in accordance with the Universal Decimal Classification. Under each number the titles are in chronological order. To ascertain what books the Library possesses on a given subject, readers are recommended to look first in the index, and then refer to the classification, before consulting the cards." By following this advice, those not already familiar with the system used in the Science Museum Library will undoubtedly save themselves both time and labour. It may be added that, in the last Report on the Science Museum, it was stated that the Library now possesses 252,515 volumes, the total of periodicals currently received is 9,468 , while the Subject Matter Index contains 2,248,423 references.

\section{Progress in France of Electricity Supply}

AN account of electricity supply in France appears in World Power of July, as a translation of a paper in La Journée Industrielle. In 1923 the total installed capacity of electrical generating stations was $4 \frac{1}{2}$ million kilowatts. This increased to $10 \frac{1}{2}$ million in 1935. There are 15 thermal and 5 hydro-electric 
stations each having a capacity greater than 100,000 $\mathrm{kw}$. The capacity has increased more rapidly than the output owing to the necessity of keeping a large reserve of power to meet sudden fluctuations in the consumption. In Paris, for example, the rate of consumption varies between $50,000 \mathrm{kw}$. at 3 a.m. and $340,000 \mathrm{kw}$. at 5 p.m. The rate of consumption of hydro-electric power is now greater than that of thermal power. It is noteworthy that the total length of the distributing lines is increasing more rapidly than the consumption of power. This is due to the increasing number of small consumers and to the fact that, as the supply service is extended to the more remote regions, longer lines are needed to reach new users. At present it is necessary to lay 46 metres of low tension line, on the average, to supply each new consumer, whereas in 1923 the length of line required was 13 metres. The large industries consume 7,100 million $\mathrm{kwh}$. per annum and electrochemistry and electrometallurgy together take 2,200. Lighting and domestic supply take 1,800 , small industries 1,000 and traction 900. There are now 35,369 communes supplied with electricity, and only about 2,600 not so provided.

\section{Protection against Gas Attacks}

THE Socialist Medical Association has issued a booklet entitled "Gas Attacks: Is there any Protection?" (London: Lawrence and Wishart, Ltd. $6 d$.$) . It is maintained that air-raiders are certain$ to penetrate our defences, and will not hesitate to employ a combination of high explosives, fire and gas in their attacks, against which the only efficient protections are respirators and gas- and bomb-proof self-contained dug-outs. The booklet issued by the Home Office, "Anti-Gas Precautions and First Aid for Air-Raid Casualties", is criticized, and is considered to give an incorrect impression of the dangers of war gases and possibilities of protection, and that the defences proposed, even if they could be generally adopted, would be inadequate. Dr. Sommerville Hastings contributes an introduction, the nature of the gases employed and their effects are described, and the available means of protection and the treatment of gas casualties are discussed.

\section{Bulletin of the Metchnikoff Institute of the Ukraine}

The Metchnikoff Institute of the Ukraine has commenced the issue of a monthly bulletin (Bulletin de l'Institut Metchnikoff) devoted in the main to bacteriological and immunological papers from the Institute, written in French, English and German. In an editorial note to the first number (April 1936), it is remarked that until 1917 bacteriology had made slow progress in Russia, but that since that time many new institutes have been established and the active roll of bacteriologists and epidemiological experts has very greatly expanded. The nineteen extremely brief papers published in the first number are written in summary fashion without bibliographies, but any efforts that facilitate the introduction of Russian work to non-Russian readers are to be heartily welcomed.

\section{The Aquarist and Pond-Keeper}

The Aquarist and Pond-Keeper, incorporating the Reptilian Review, in the March-April number, 1936, has various improvements, including a new cover design. Specially striking is a collection of photographs occupying two pages, which with the illustrations to the article on reptile hunting in Britain by A. E. H., depict the whole of our native species of reptiles and batrachians. Mr. E. Bridgstock-Choat, honorary curator of the Erith Museum, contributes an article entitled "The Pond Hunter", which will be continued, and papers from various other workers deal with fishes, fish-breeding, ponds and water gardening and various allied subjects.

\section{Official Statistics}

Atrention may be directed to the publication of the Guide to Current Official Statistics for 1935 (London: H.M. Stationery Office. Price 1s.). The arrangement is the same as in previous years. The greater part of the volume is occupied by an alpha. betical range of subjects with reference to the appropriate publication. This is followed by a list of publications arranged under departments. The volume is invaluable for quick reference, and reveals the great range of matters on which statistical and other official information is available.

\section{Post-graduate Medical Research}

The Medical Research Council has decided to institute a series of studentships and fellowships to encourage young British medical graduates towards becoming investigators in those branches of medical science which are concerned directly with disease as it occurs in human beings. Six post-graduate studentships are therefore offered for medical graduates who have already held house appointments and are strongly inclined to a career in clinical science or experimental pathology. Each selected student will receive an inclusive grant at the rate of $£ 200$ per annum, during a period not exceeding twelve months, while undertaking approved courses of study in Great Britain such as may be regarded as best calculated to advance the student's training in methods of research. Four research fellowships are also offered for candidates of similar qualifica. tions who have already had some experience in research methods. Each fellowship will be tenable for one year at the value of $£ 250$ per annum, and will be renewable in approved instances at the rate of $£ 300$ per annum for a second year. Further information can be obtained from the Secretary, Medical Research Council, 38 Old Queen Street, London, S.W.1.

\section{Fireball over Yorkshire}

The occurrence on August 18 at about $22^{\mathrm{h}} 23^{\mathrm{m}}$ (Summer Time) of a brilliant object, evidently a fireball or particularly bright meteor, has been referred to by several correspondents in the Yorkshire Post. The accurate observation of the apparent path of a meteor requires a trained observer, and it is to be expected that accounts supplied by casual eye- 